\title{
Digital Enterprise Architecture for Green SPBE in Indonesia
}

\author{
Indri Sudanawati Rozas ${ }^{* 1}$, Khalid ${ }^{2}$, Nita Yalina ${ }^{3}$, Noor Wahyudi ${ }^{4}$, \\ Dwi Rolliawati ${ }^{5}$ \\ 1,2,3,4,5Information System Department, Faculty Science and Technology, UIN Sunan Ampel \\ Surabaya, Indonesia

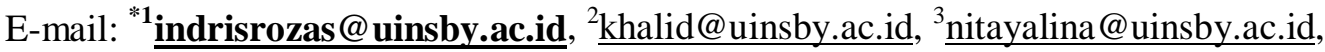 \\ ${ }^{4}$ n.wahyudi@uinsby.ac.id, ${ }^{5}$ dwi_roll@uinsby.ac.id
}

\begin{abstract}
SPBE (Electronic Based Government System) is a legal protection as new breakthroughs in the reform of Indonesian government bureaucracy. The issuance of Presidential Regulation (Perpres) 95/2018 concerning SPBE is expected to be a reference for the transformation from e-Government into i-Government (integrated Government). In the meantime, the government through the Ministry of Administrative and Bureaucratic Reform (PANRB) is drafting an academic paper on the SPBE Bill. Of the 10 elements contained in Presidential Regulation (Perpres) 95/2018, the second element namely SPBE architecture is a concept known in the world of Information Systems as Enterprise Architecture.

Enterprise architecture is a conceptual framework that describes how an enterprise is constructed by defining its primary components and the relationships among these components. In SPBE, the main component is defined as domain, consisting of 6 parts, namely: business process architecture domain, data and information, infrastructure, SPBE applications, security, and SPBE services. Unfortunately, the Presidential Regulation (Perpres) 95/2018 has not regulated the concept of Digital Enterprise Architecture, since between Enterprise Architecture (EA) and Digital Enterprise Architecture (DEA) are two things that are significantly different. If EA merely focuses on structuring the company based on the main frame of reference, then DEA focuses on utilizing digital repositories to create living documents as according to the EA framework so that they are easily accessed, modified and managed at any time following the company's development. This study created a DEA model for SPBE in Indonesia. The model created is adapted to the SPBE architecture by carrying out the concept of a digital repository. With digital repositories, time efficiency, paper savings and change management will be easier to achieve. The model created in this study is expected to be utilized to make SPBE much more efficient and green-minded.
\end{abstract}

Keywords - Digital Enterprise Architecture, Digital Repositories, Framework, Green, SPBE.

\section{INTRODUCTION}

SPBE is a government administration using information and communication technology to provide services to users of electronic-based services [1]. SPBE is also widely known as e-government [1]. The first legal protection for implementing SPBE is Presidential 
Regulation (Perpres) 95/2018 concerning Electronic-Based Government Systems (SPBE). However, the Presidential Regulation (Perpres) only regulates the government agencies in implementing an integrated SPBE [2]. Thus, in order that all public society could also enjoy the implementation of such integrated-electronic-based services, the government is currently formulating an academic paper on a draft bill (RUU) concerning an electronic-based government system (SPBE) [3]. The issuance of such SPBE Law is aiming to protect the interests of the government, public society, business people, entrepreneurs, and other stakeholders in implementing SPBE, including imposing and applying punishments on irresponsible parties [2].

In accordance with the schedule set out in the Presidential Regulation (Perpres), currently what is being worked on is the first two elements, namely the National SPBE Master Plan and the National SPBE architecture [3]. The SPBE architecture is a basic framework that describes the integration of business processes, data and information, SPBE infrastructure, SPBE applications, and SPBE security to produce integrated SPBE services, and is compiled for a period of 5 years [4]. To formulate the National SPBE architectural policy and the National SPBE Plan Map, the basis reference is the 2020-2024 RPJMN Document [4]. On January 17, 2020, President Joko Widodo (Jokowi) signed Presidential Regulation (Perpres) 18/2020 concerning the 2020-2024 National Medium-Term Development Plan (RPJMN) [5]. This is interesting that even though to formulate the SPBE architecture uses the RPJMN document, yet in the attachment of Presidential Regulation (Perpres) stated that the SPBE is used as material for the evaluation of the RPJMN through the Integrated Information System, Evaluation and Control (SITEP) [6].

The reason why SPBE is actually part of the RPJMN evaluation material is not quite surprising, since in 2019, Bambang Dwi Anggono, Director of Government Aptika Services (LAIP) stated that SPBE is actually a transformation from the e-Government era into iGovernment (integrated Government) [7]. The i-Government itself is the implementation and application of smart government, a system which is integrated one into another, that between each system could interact and produce data which mutually support the inter-system processes, and the data results can be used as a reference for decision making in the development planning and problem solving [7].

Based on the previous explanation, we can conclude that SPBE has a very important role in the efforts to reform the bureaucracy in order to achieve and implement good governance. In reference to the preparations made, the direction of developing the SPBE architecture is a concept known as an enterprise architecture (EA), which is specifically named as Small and Efficient One-Government Through Integrated and Interfaced Computerization [4].

EA is a conceptual framework that describes how an enterprise is constructed by defining its primary components and the relationships among these components [8]. The concept of EA was actually first put forward by John Zahman in 1987 with a manuscript entitled A Framework for Information Systems Architecture [9]. Referring to the hype cycle issued by Gartner as shown in Figure 1, for about 9 years the EA concept was in the "technology trigger" phase by the Zachman framework until then The Open Group's Architecture Framework (TOGAF) followed by issuing its first framework in 1994. Since then, EA through the TOGAF framework experienced a phase of "peak of inflated expectations" in 2002 [10]. 


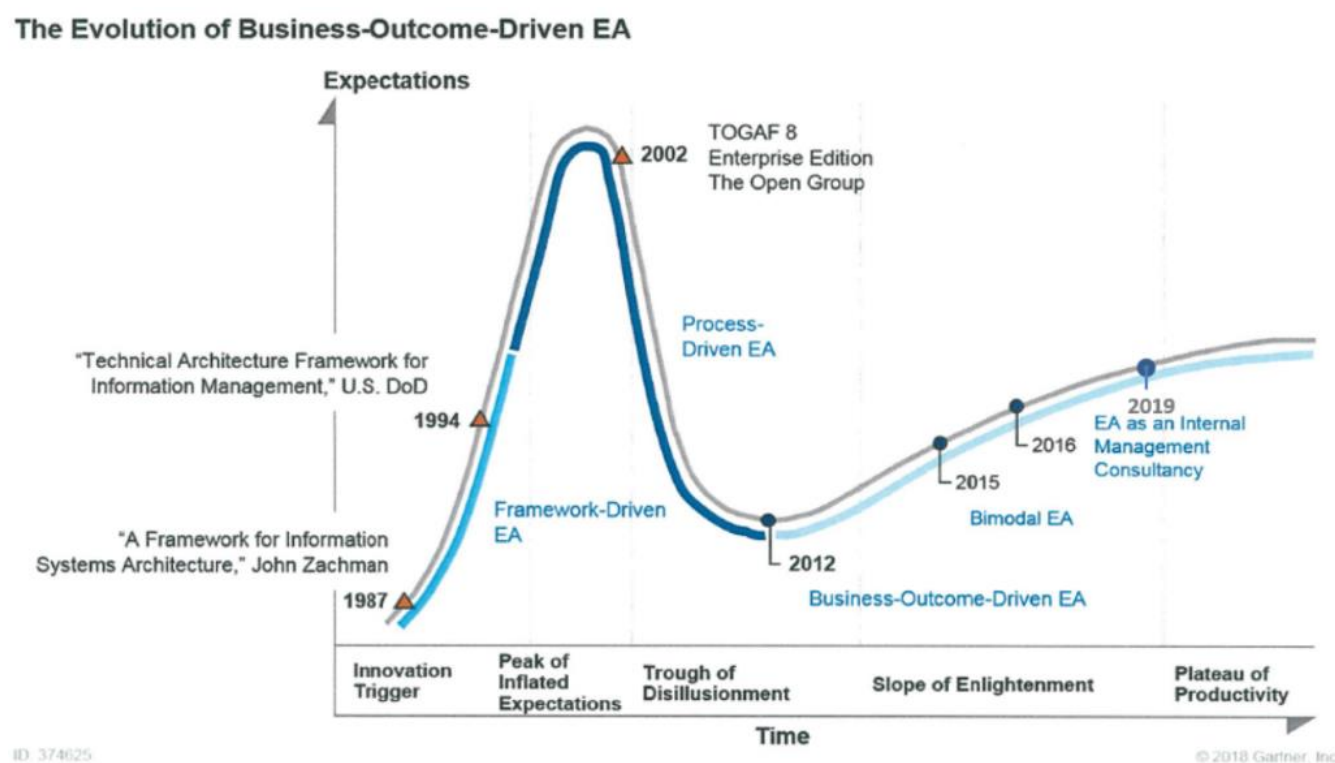

Figure 1. The Evolution of Business-Outcome-Driven EA by Gartner [10]

It was from 2002 to 2012 that TOGAF entered the phase of "thorough of disillusionment", since it failed to meet the expectations. Whereas during the $2002-2012$ phase, TOGAF actually issued 5 frameworks to continue improving the previous framework to the better ones. They are namely TOGAF 7 (2002), TOGAF 8 (2003), TOGAF 8.1 (2006), TOGAF 9 (2009), and TOGAF 9.1 (2011). Lots of frameworks were released in that phase, yet EA was already considered a concept that did not bring any contribution to business. Until then in 2012 EA eventually entered the "slope of enlightenment" phase, meaning new hopes began to emerge. The development of IoT makes business people feel the need to manage everything better and faster. And finally, 2019 is considered to be the beginning phase of the "plateau of productivity" in which with the help of IoT, digital EA is considered to be more stable, worthwhile, useful, beneficial, widely practiced and accepted by organizations [10]. This phase will continue, even as predicted by Gartner that by 2021, $40 \%$ of organizations will use enterprise architects to help ideate new business innovations made possible by emerging technologies [11].

Gartner's statement that from 2002 to 2012 the EA concept experienced a bleak phase for its failure to meet expectations, indeed attracted many researchers, one of which is Tom Hope et al. In 2017 with the title of publication: "The Failure of Success Factors: Lessons from Success and Failure Cases of Enterprise Architecture Implementation" [12]. In his paper, Tom said that indeed many EA programs have failed to meet the expectations. And after conducting a series of studies, it was concluded that: success in EA programs comes more from how architecture is practiced than what is practiced [12]. This is in line with the results of research by Yiwei Gong in 2019 entitled "The value of and myths about enterprise architecture" [13]. In this study he conducted SLRs to identify why there are myths and claims that EA is an instrument that can solve almost all kinds of corporate problems [13]. In fact, he concluded that the EA concept itself does not provide value, yet it is an instrument that possibly allows value to be created [13]. It is necessary to demystify and simplify the EA concept to avoid misperception and overly high expectations [13]. 
Then how shall we interpret EA properly in order to achieve benefits and not fall into mythical mistakes? Graeme Shanks et al in 2018 tried to formulate an answer through a publication entitled "Achieving benefits with enterprise architecture" [14]. He made a conceptual model as shown in Figure 2, which was then proven by a series of studies. He proved that the influence of the traditional governance-based approach was not as strong as the impact of the emerging service provision approach to EA. He also proved through a model that, to achieve optimal success, EA governance and EA service must be carried out dynamically with the help of IT-Driven Change and Business-Driven Change [14].

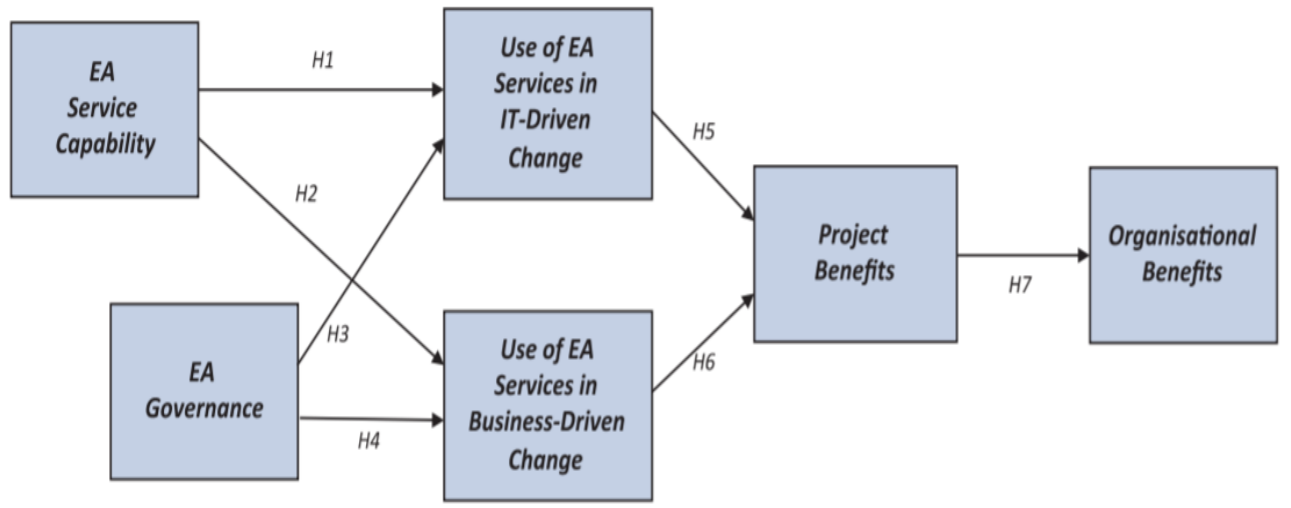

Figure 2. Model Conceptualises: How EA Service Capability Leads to Organisational Benefits

[14]

In reference to the keyword IT-driven change, this is in line with the research of Hope, et al. [12] and Gong [13] that the EA concept which is not implemented efficiently and comprehensively will avoid the organization from achieving benefits. This is what then underlies a lot of research that directs EA to the concept of automation in its implementation. Roy Oberhauser in 2019 created a new framework called the Digital Diamond Enterprise Framework. This framework proposes an alternative EAF that is digital, holistic, and digitally sustainable [15]. Another researcher who is concerned much with the concept of automation at EA is Alfred Zimmermann. There have been dozens of publications on such concepts. Starting from 2015 there was an early publication called adaptive EA [16]. Then continued in the same year given the name adaptive digital enterprise architecture [17]. Next, Alfred emphasized the DEA concept in relation to the internet of things [18]. Furthermore, he discussed how management makes decisions through the DEA [19]. He also focuses on how to make an adaptable DEA with microservices [20]-[22], then implement it into architecture management in tourism-state of the art and future directions [23]. Starting in 2018, Alfred still continues to discuss micro-granular digital services and products [24] and then links it to digital transformation processes and also software engineering [25][26][27][28][29]. Alfred's latest publication is available in 2020 entitled "Evolution of Enterprise Architecture for Intelligent Digital Systems" which utilizes an adaptive architecture integration approach for open-world integrations of globally accessed systems and services. This is relatively new in the world of EA, even though in its implementation there are still limitations to its IoT integration technology, mainly in the integration process of analytics-based decisions support and contextdata driven architectural decision-making [30].

So, what is the main core concept of the digital EA? Referring to the whole concept brought by Alfred Zimmermann and additional literature research [31] and [32], the main core 
concept of digital EA is automatic documentation of micro services. In this study, such a concept of automatic documentation will be applied in the implementation of SPBE in Indonesia.

As discussed previously in the introduction and gap analysis, this study aims to create a model for implementing the SPBE architecture using the concept of automatic documentation as in DEA. The model created in this study is expected to be utilized to make SPBE much more efficient and green-minded, and hopefully not experiencing failures as in the past traditional EA.

\section{DIGITAL ENTERPRISE ARCHITECTURE CONCEPT}

To create a green SPBE model later in part III, now in this part II we will discuss in detail main concepts that form the basis of green SPBE.

\section{a. Enterprise Architecture Principles}

Enterprise Architecture consists of 21 principles as shown in Table 1. Each of the principles according to the layer (business layer, data layer, application layer, and technology layer) in Table 1 must be met to get a good EA product. However, the 21 principles for these 4 (four) layers are still standard. EA has not mentioned the implementation of the green principle in it.

Table 1. Architecture Principle of EA [40]

\begin{tabular}{|l|l|c|c|}
\hline \multicolumn{1}{|c|}{ Business Principles } & \multicolumn{1}{|c|}{ Data Principles } & \multicolumn{1}{c|}{$\begin{array}{c}\text { Application } \\
\text { Principles }\end{array}$} & $\begin{array}{c}\text { Technology } \\
\text { Principles }\end{array}$ \\
\hline P01: Primacy of Principles & P10: Data is an Asset & P16: Technology \\
P02: Maximize Benefit to & P11: Data is Shared & P18: Requirements- \\
the Enterprise & P12: Data is Accessible & P17: Ease-of-Use & Based Change \\
P03: Information & P13: Data Trustee & & $\begin{array}{c}\text { P19: Responsive } \\
\text { Change }\end{array}$ \\
Management is & P14: Common & & Management \\
Everybody's Business & Vocabulary and Data & & P20: Control \\
P04: Business Continuity & Definitions & Technical \\
P05: Common Use & P15: Data Security & & Diversity \\
$\quad$ Applications & & & P21: Interoperability \\
P06: Service Orientation & & & \\
P07: Compliance with Law & & & \\
P08: IT Responsibility & & & \\
P09: Protection of & & & \\
Intellectual Property & & & \\
\hline
\end{tabular}

b. Enterprise Architecture Framework

To manage the scale and complexity of an enterprise system, a framework guidance is certainly necessary, which is commonly called the Enterprise Architecture Framework (EAF). EAF provides tools and approaches that give an abstraction from the detail level up to the design-level of enterprise helicopter view, including the architectural documentation which is 
considered valuable. There have been many EAFs available since 1987, when Zahman introduced the framework [9]. Susanne Leist and Gregor Zellner in 2006 made a review and evaluation towards several existing EA frameworks, which was published entitled "Evaluation of Current Architecture Frameworks". The seven frameworks being analysed were: ARIS, C4ISR (Command, Control, Communications, Computers, Intelligence, Surveillance, and Reconnaissance) and DoDAF (Department of Defence Architecture Framework), FEAF (Federal Enterprise Architecture Framework), MDA (Model Driven Architecture), TOGAF (The Open Group Architecture Framework), and Zachman. The evaluation results towards the seven EAFs are presented in Figure 3 below [35].

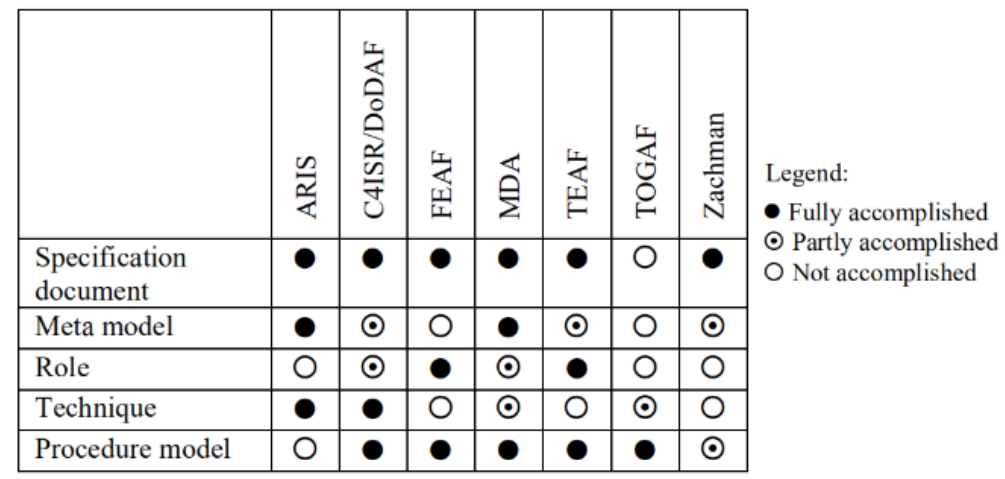

Figure 3. Evaluation towards 7 Enterprise Architecture Framework [35]

Figure 4 shows that each framework has its own strengths and weaknesses, and there is no framework that meets all the requirements regarding the constitutive elements of an EA method. Another interesting result from [35] is that each EAF has balanced strengths and weaknesses, thus based on such evaluation it can be used to consider which EAF is chosen according to the objectives and circumstances of the company.

In the same year, a group of researchers from Michigan University conducted a study entitled "A Comparison of Enterprise Architecture Frameworks" which compares EAF with 5 framework objects, namely: Zachman, DoDAF, FEAF, TEAF, and TOGAF. The conclusions on the comparison of each framework are shown in Table 1 [36].

Table 2. EAF Comparison by Views/Perspectives

\begin{tabular}{|c|c|c|c|c|c|c|}
\hline Framework & Planner & Owner & Designer & Builder & Subcontractor & User \\
\hline Zachman & Scope & $\begin{array}{c}\text { Business } \\
\text { Model }\end{array}$ & $\begin{array}{l}\text { System } \\
\text { Model }\end{array}$ & $\begin{array}{l}\text { Technology } \\
\text { Model }\end{array}$ & $\begin{array}{c}\text { Detailed } \\
\text { Representations }\end{array}$ & $\begin{array}{c}\text { Functioning } \\
\text { System }\end{array}$ \\
\hline DoDAF & All View & $\begin{array}{c}\text { Operational } \\
\text { View }\end{array}$ & $\begin{array}{l}\text { Systems } \\
\text { View }\end{array}$ & $\begin{array}{l}\text { Technical } \\
\text { View }\end{array}$ & & \\
\hline FEAF & $\begin{array}{l}\text { Objectives/Scope } \\
\text { Planner's View }\end{array}$ & $\begin{array}{c}\text { Enterprise } \\
\text { Model } \\
\text { Owner's } \\
\text { View }\end{array}$ & $\begin{array}{c}\text { Information } \\
\text { Systems } \\
\text { Model } \\
\text { Designer's } \\
\text { View }\end{array}$ & $\begin{array}{c}\text { Technology } \\
\text { Model } \\
\text { Builder's } \\
\text { View }\end{array}$ & $\begin{array}{c}\text { Detailed } \\
\text { Specifications } \\
\text { Subcontractor's } \\
\text { View }\end{array}$ & \\
\hline TEAF & Planner & Owner & Designer & \multicolumn{2}{|c|}{ Builder } & \\
\hline TOGAF & & $\begin{array}{c}\text { Business } \\
\text { Architecture } \\
\text { View } \\
\end{array}$ & \multicolumn{2}{|c|}{$\begin{array}{c}\text { Technical Architecture } \\
\text { Views }\end{array}$} & & \\
\hline
\end{tabular}


The comparison between each EAFs in Table 2 can be taken into consideration for each party in choosing a framework that suits their needs.

c. Digital Enterprise Architecture Framework

As discussed by Roy Oberhauser, currently is the era of the Digital Enterprise Architecture Framework (DEAF), which is a digital, holistic, and digitally sustainable DEA [15]. And the implementation of the Digital Diamond Framework made by Roy Oberhauser is illustrated in Figure 4.

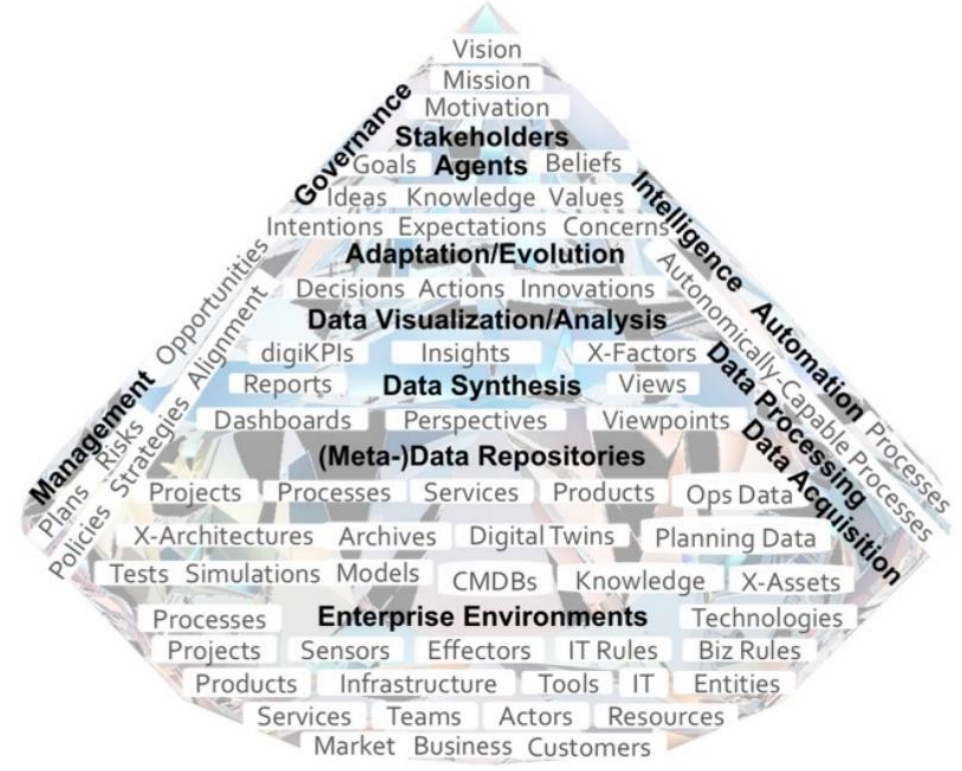

Figure 4. Illustration of Digital Diamond Framework [15]

Figure 4 shows an illustration of how the role of IoT is optimized for the EA environment so that it could meet its efficiency. Such a concept inspiring an idea for the green EA concept towards the proposed green SPBE. The exact definition of green EA is actually covered in the terminology of Green Computing, which is concerned on how to use computers that are environmentally responsible by reducing energy consumption and minimizing waste to the environment [37]. Meanwhile, Green Computing has become one of the research focuses in the Information Systems department of UIN Sunan Ampel Surabaya with the concept of Islamic Green Computing (IGC) [38]. Islamic Green Computing is the concept of using computing devices with the principle of efficiency so as to save resources from both the producer and consumer [38]. The example of such ICG implementation is a digital workplace [39].

\section{GREEN ENTERPRISE ARCHITECTURE MODEL}

Based on the fundamental concepts presented in the previous sub-chapter, the following chapter describes the green SBPE model in Indonesia: 


\section{a. Electronic-Based Government System (SPBE) Component}

SPBE is still under the legal protection of Presidential Regulation (Perpres) 95/2018, and yet to better protect the interests of government and public society, the SPBE Bill is currently being drafted [2]. In the Presidential Regulation (Perpres) 95/2018, it is stated that there are 10 components of SPBE, namely [33]:

1) National SPBE Master Plan;

2) SPBE architecture;

3) SPBE Plan Map;

4) SPBE plan and budget;

5) Business Process;

6) Data and information;

7) SPBE infrastructure;

8) SPBE application;

9) SPBE security; and

10) SPBE services

The relationships among these 10 components depicted visually in Figure 5.

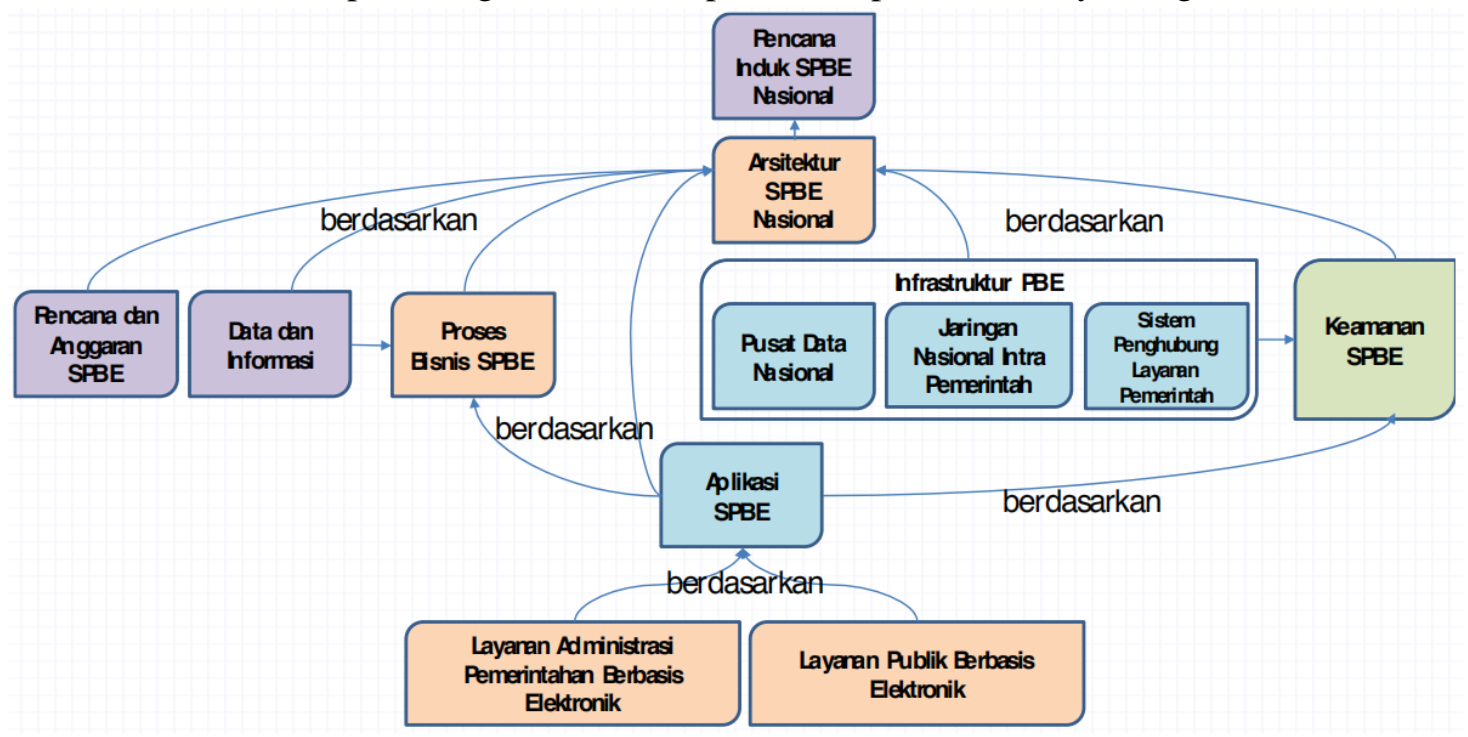

Figure 5. The relationships among SPBE 10 components [34]

Figure 5 clearly showed that each part is interrelated, becomes input and provides output respectively to other components. The question is on how to handle changes that occur in one component which turns out to affect other elements. This is where the concept of automatic documentation will play a very important and significant role in increasing efficiency. However, until now there is no regulation that explains how to store documentation of all these components so that it is easy to do tracing and updating.

\section{b. Green EA Practices}

This paper focuses on the green SPBE architecture where according to Table 1 EA principles, an EA must have the 21 principles mentioned. And Table 1 above still has not 
mentioned the basic concept of green, while according to our model, these green practices become general principles in green EA as illustrated in Figure 6. Based on Figure 6, all practices in Business, Data, Application and Technology layer should comply with green computing principles. Rationale: if the digital transformation is projected within the Enterprises then the objective should lead to environmental sustainability. Implications of green EA principles is:

a) Business value should be delivered while considering about effectivity and efficiency of resources

b) Data that remain in the storage must not redundant and historical data should be mined and give value to the business

c) Application catalogue must be updated but keep in mind that all the resources must be used effectively and efficiently

d) Technology infrastructure must be in its best condition to prevent abundant use of electricity

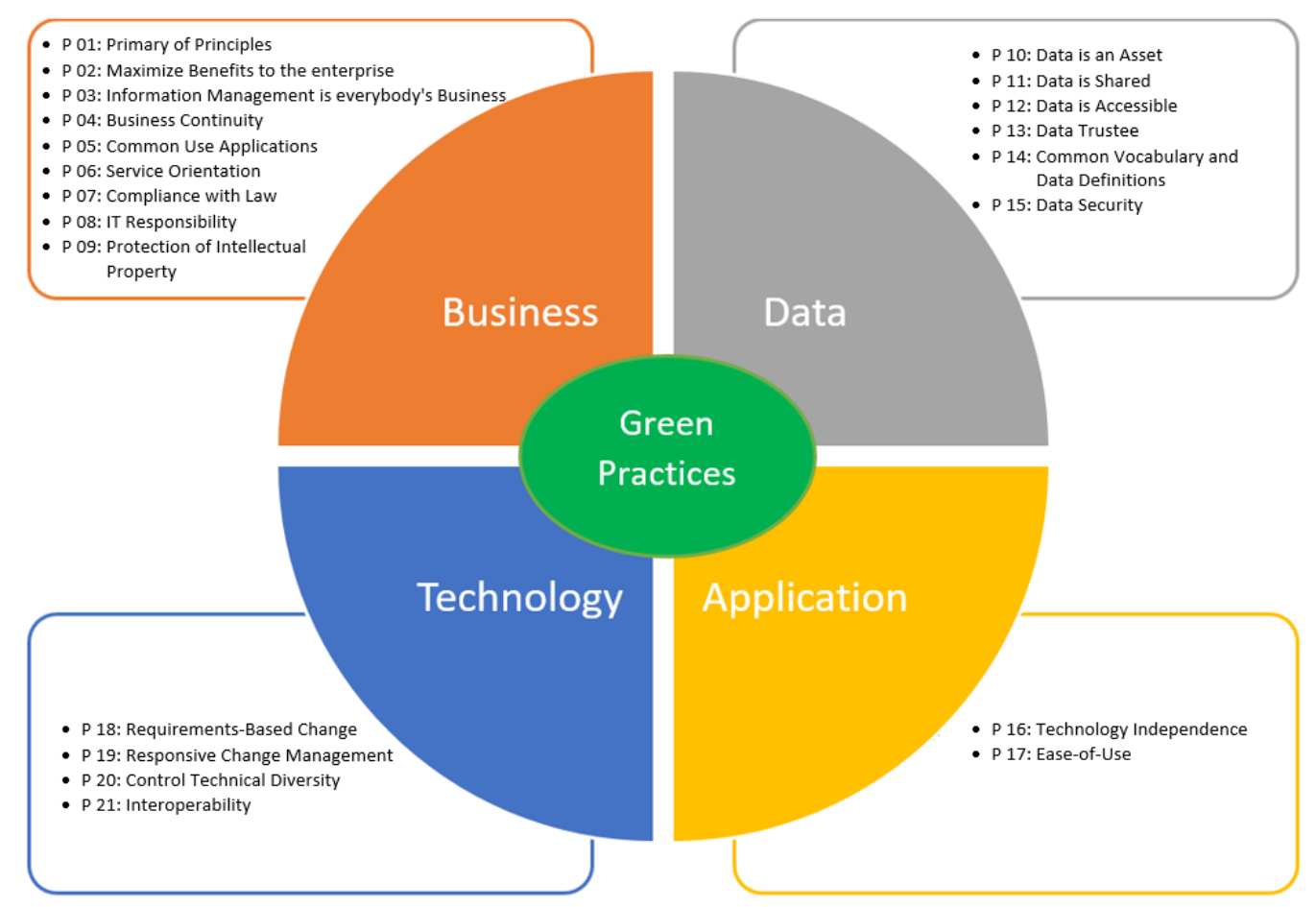

Figure 6. Green Practices as General Concept in Green EA Principle

c. Green SPBE Value Chain Diagram

Refer to the Presidential Regulation (Perpres) 95/2018 [33] SPBE architecture has 6 (six) architecture domains, namely:

1) Business Process;

2) Data and information;

3) Infrastructure;

4) Application;

5) SPBE Security; and

6) SPBE Services. 
However, until now there is still no explanation/discussion from the government on what the model should be for such six domain architectures. As well as for the National SPBE value chain diagram, we still have not found related publication. In this study, the green value chain models for green SPBE are based on the Islamic Green Computing concept in Figure 7.

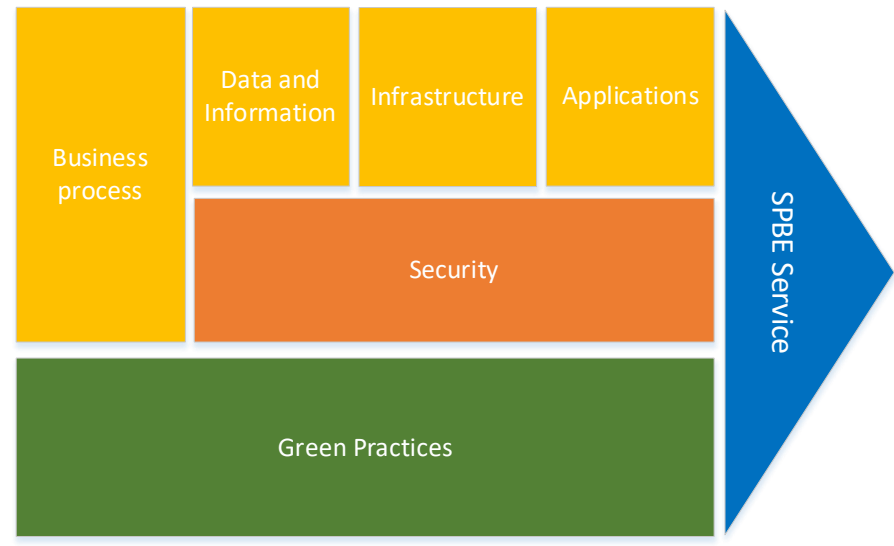

Figure 7. Green Value Chain model of SPBE architecture

In accordance to the Presidential Regulation (Perpres), the security domain must cover data and information, infrastructure, and applications. This study creates a value chain model by incorporating green practices components for green SPBE. With the green concept, the efficiency principle of digital EA certainly will be achieved. Hopefully, the DEA as the basis concept for the green SPBE will work out and not experiencing failures as the traditional EA concept.

\section{d. Green EA Implementation Example}

Figure 8 below is an example of an enterprise architecture product that has implemented the green EA principle concept. The framework is called the Integrated Multidimensional Enterprise Architecture (idEA) by Romi Satria Wahono. This framework was presented extensively at the 2021 National Seminar on Research and Technology [41].
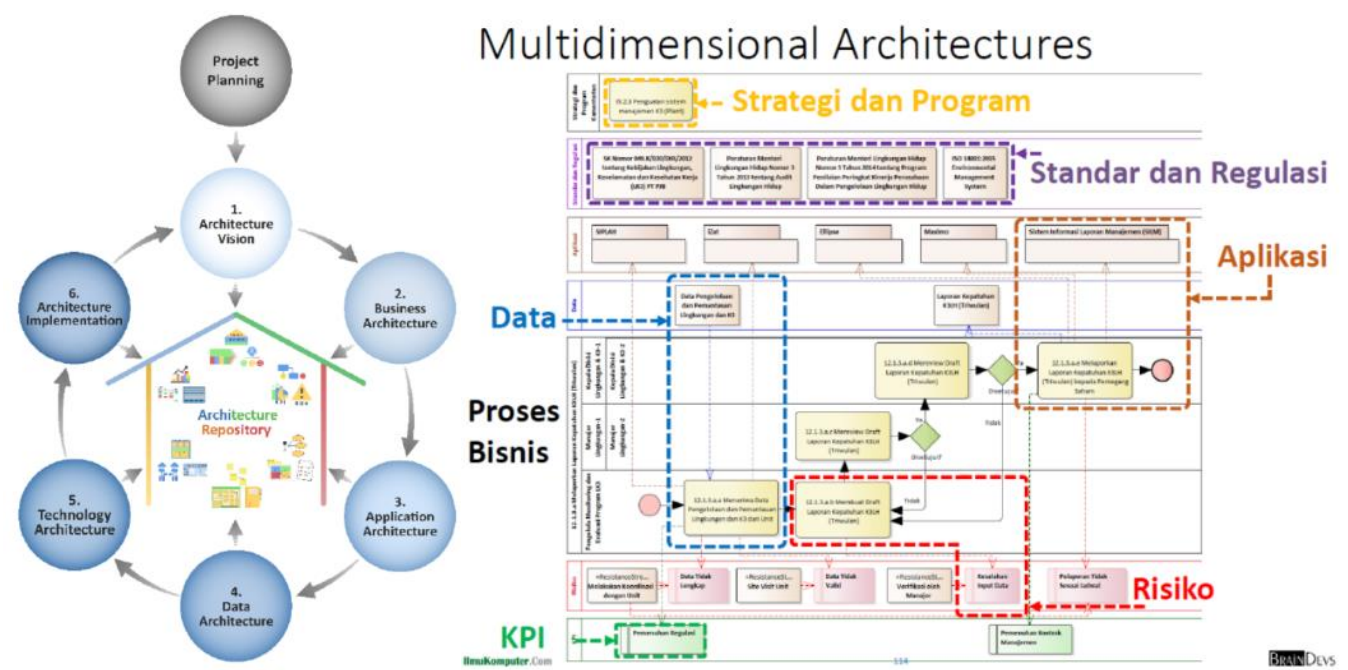

Figure 8. Framework idEA (Romi Satria Wahono, 2021) [41]. 
The idEA framework refers to the simplified TOGAF framework systematics as shown in Figure 8 on the left. The idEA framework states that it uses the Simplified Systematic Method concept with its main strengths being the Architecture Repository and Multidimensional Architecture (Figure 8 on the right). By using this concept, idEA has become paperless and also easy to track when there are changes in real time. idEA has been implemented in many organizations, including: Pertamina EP, PJB, LIPI, Politenik Pos Indonesia, Australian Aid, Pos Indonesia, KPK, INSW, Ministry of Finance and so on. At the Ministry of Finance, idEA implementation received an award as the institution with the best SPBE implementation in 2018. For PJB, idEA implementation has led the company to receive the Malcom Baldrige award in 2019. Then the implementation of idEA at the National Scientific Repository Repository Ilmiah Nasional (RIN) at LIPI also received the TOP award digital implementation 2019. The award won by idEA is also an acknowledgment that the digital repository not only makes everything green, but also supports the achievement of the organization's vision effectively and efficiently.

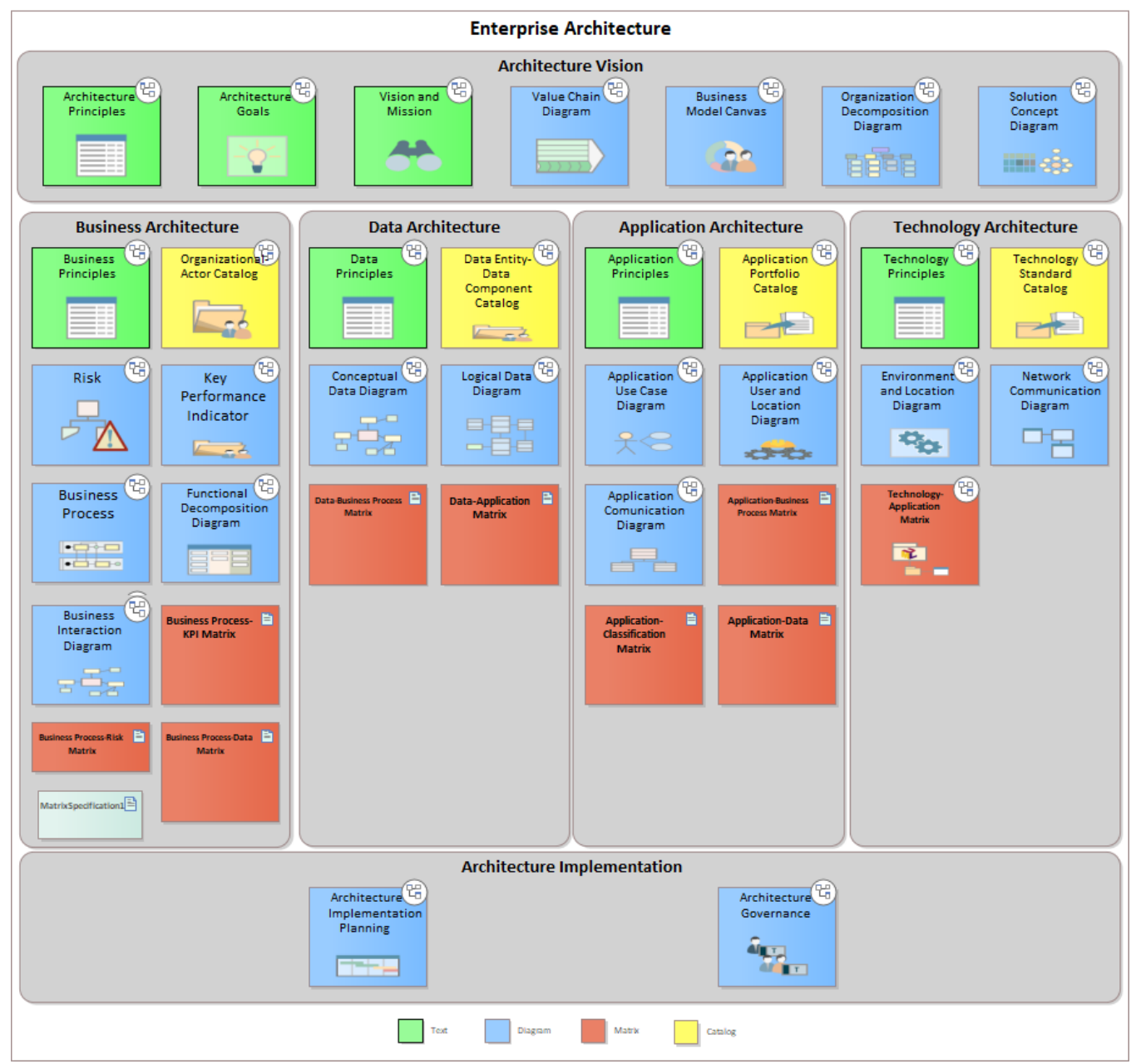

Figure 9. Template idEA Dashboard 


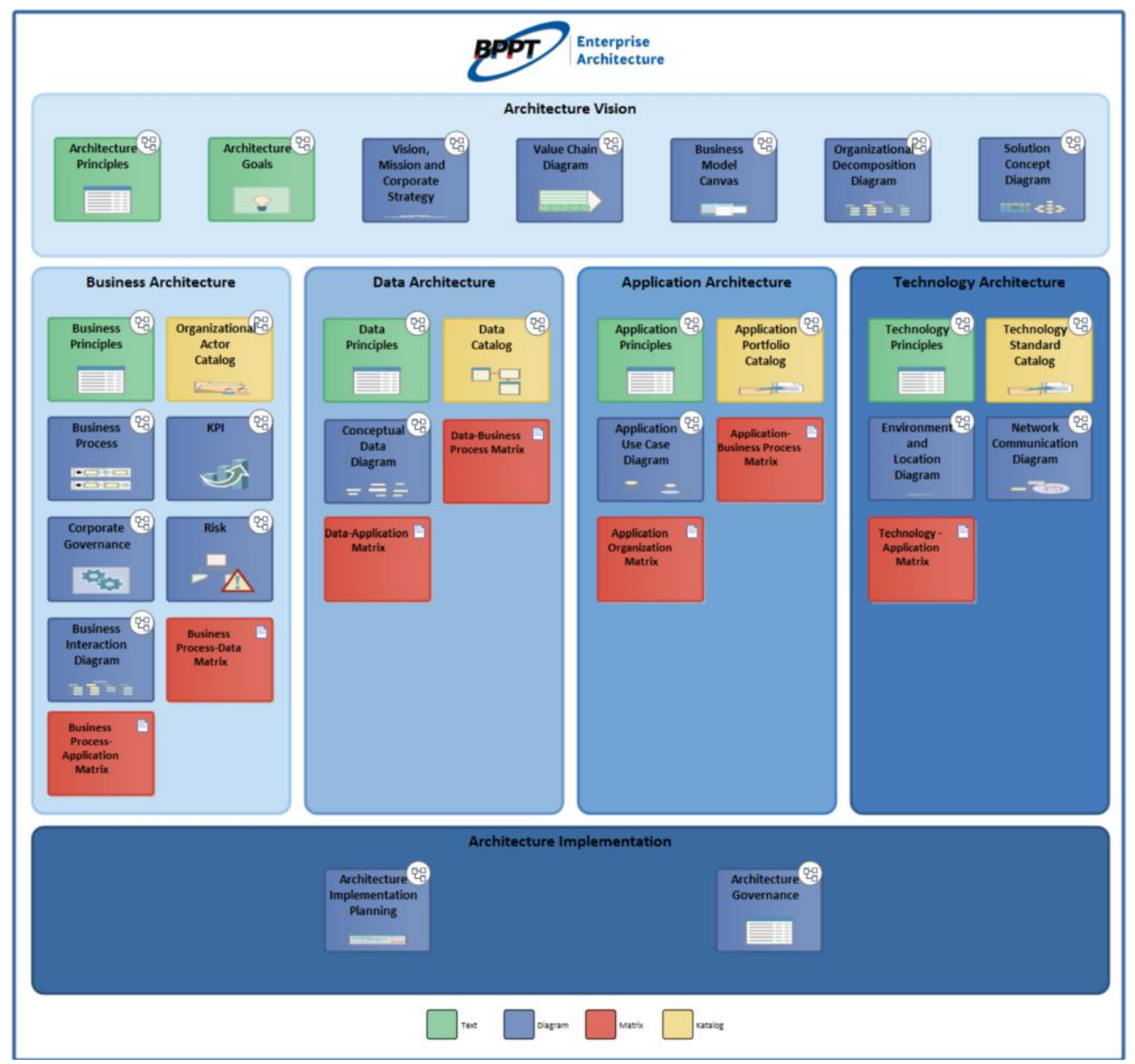

Figure 10. Example of EA Dashboard

The key to the efficiency and effectiveness of idEA is in the implementation of digital repository which is materialized in a SparxEA-based application. When the conventional EA concept is adopted and applied, all documents though already in form of digital files, they would be located into separated storage. Thus, in Digital EA application the storage is located/united in similar repository, and to open it, takes only one step from the existing dashboard. Figure 9 above shows an idEA template which is shared and free to use for educational purposes. While Figure 10 displays BPPT's EA Dashboard, which can be benefited to make the tasks visualization and organizational functions much clearer. In addition, by applying a unified digital repository, it would make organization visualizations at various levels of abstraction easy to understand, thus it can be used as the basis to create a roadmap for organizational transition plans as well as future targets and goals.

\section{e. Green SPBE Dashboard}

In refer to the implementation of green EA on the idEA dashboard template and its implementation on BPPT, as well as considering the SPBE Component, Green EA Practices, Green SPBE Value Chain Diagram, the model in Figure 11 below is the proposed dashboard design. 


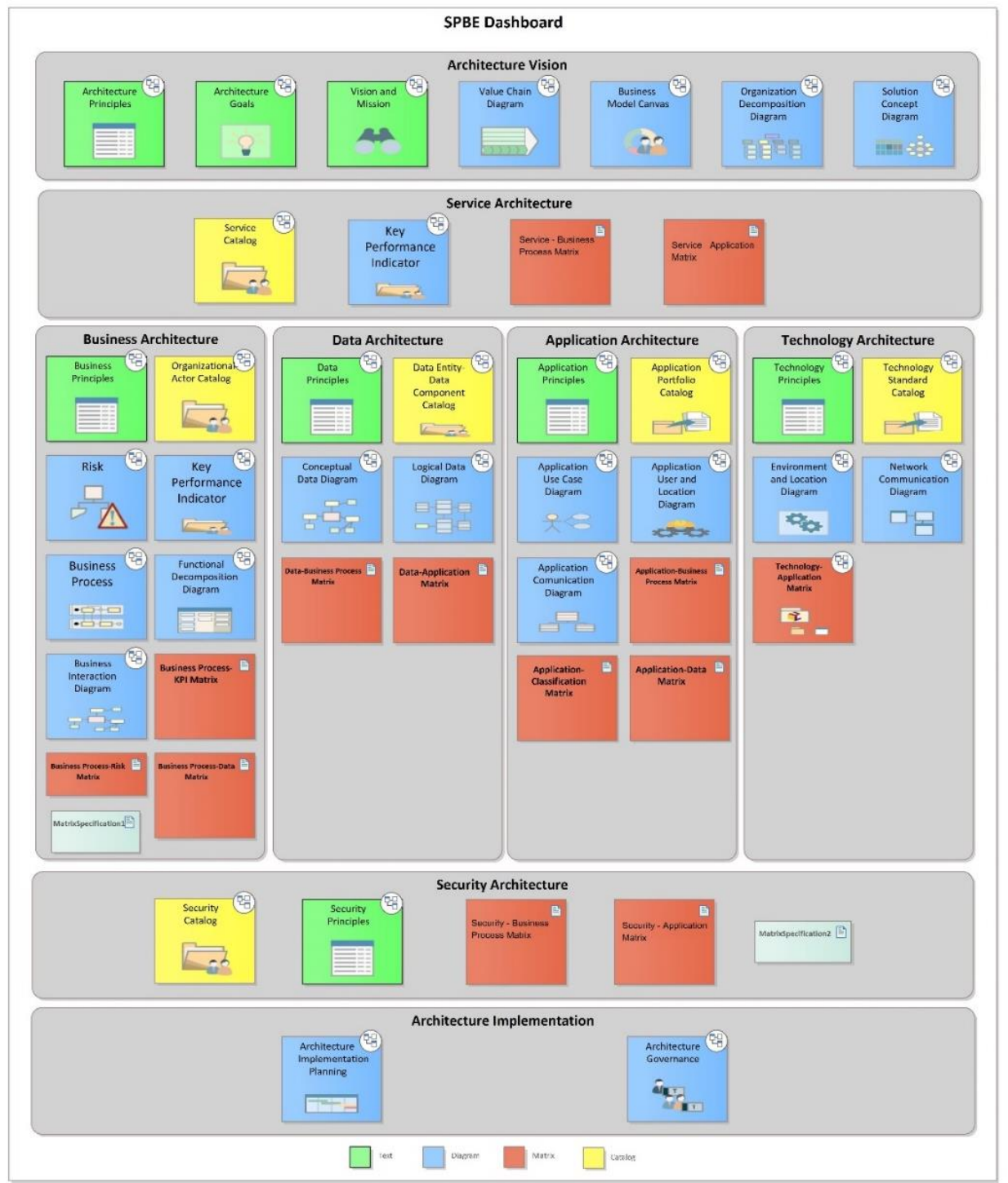

Figure 11. Model of Green SPBE Dashboard

The basic differences between the green SPBE dashboard model and the idEA template in Figure 9 are: the green SPBE Dashboard model contains 6 (six) architecture domains, namely: Business Process; Data and information; Infrastructure; Applications; SPBE Security; and SPBE Services. While the idEA template contains only 4 (four) domains, namely: Business Process; Data and information; Infrastructure; and Applications.

\section{CONCLUSION}

Based on the given explanation in the previous sub-chapter, the results of this research are there are three models observed, namely: Green EA Practices, Green SPBE Value Chain Diagram, and Green SPBE Dashboard. The following are the results and analysis of the three models compared to the EA concept;

a. Green EA Practices

In this study, the proposed model is the inclusion of the green practices concept as the foundation for the previously existing 21 EA principles.

b. Green SPBE Value Chain Diagram 
In the green SPBE value chain model created, green practices are included as supporting activities that complement national 6 (six) SPBE architectural domains. In this value chain, domain services are also created as the main goal of SPBE, and this is in line with the presence of SPBE which aims to maximize services to the society.

c. Green SPBE Dashboard

The green SPBE dashboard model is the main result answering the research problem on "how a digital EA makes SPBE in Indonesia much greener (effective and efficient)." With this dashboard, all of many available EA artifacts could be seen and monitored from one main screen, thus making it easier to provide understanding. In addition, the one-dashboard model is an implementation of a digital repository that allows all artifacts to be connected one another so that when there appears any updates, it is easier to apply.

\section{SUGGESTED}

Based on the overall discussion, it can be concluded that traditional EA has failed and has been quite disappointing, even though the principles of EA are actually still very relevant to be solution to problem for organizational management in the future. To anticipate such failures, EA's digital concept is the answer. Digital EA applies an efficiency principle, with its main implementation is document automation. Such efficiency principle is in line with the concept of Islamic Green Computing (IGC). Based on IGC and DEA, this study makes green practices a recommendation for green SPBE for Indonesia. In this study, there are three conceptual points result, namely: Green EA Practices, Green SPBE Value Chain Diagram, and Green SPBE Dashboard. The first two concepts are the conceptual foundations (Green EA Practices, Green SPBE Value Chain Diagram), while the Green SPBE Dashboard is a dashboard template which is very relevant to be used as a reference for effective and efficient SPBE products in line with the spirit of green computing

\section{REFERENCES}

[1.] S. K. Adi Surya, "Penerapan Enterprise Architecture (EA) Untuk Mendukung Sistem Pemerintahan Berbasis Elektronik (SPBE)," Pusdatin Setjen PU, pp. 1-4, 2018.

[2.] Imam Machdi, "Kementerian Pendayagunaan Aparatur Negara dan Reformasi Birokrasi - Pemerintah Susun RUU SPBE,” Menpan.go.id, 2019. [Online]. Available: https://www.menpan.go.id/site/berita-terkini/pemerintah-susun-ruu-spbe. [Accessed: 16-Sep-2020].

[3.] Imam Machdi, "Kementerian Pendayagunaan Aparatur Negara dan Reformasi Birokrasi - FGD Penyusunan Model Referensi Arsitektur SPBE,” Menpan.go.id, 2019. [Online]. Available: https://www.menpan.go.id/site/berita-foto/fgd-penyusunan-modelreferensi-arsitektur-spbe-2. [Accessed: 16-Sep-2020].

[4.] Imam Machdi, "PENYUSUNAN ARSITEKTUR DAN PETA RENCANA SPBE NASIONAL 2020-2024," Kementeri. Pendayagunaan Apar. Negara dan Reformasi Birokrasi, 2020.

[5.] Sekretariat Kabinet RI, "Sekretariat Kabinet Republik Indonesia | Presiden Teken Perpres No. 18/2020 tentang RPJM Nasional Tahun 2020-2024- Sekretariat Kabinet 
Republik Indonesia," Setkab.go.id, 2020. [Online]. Available: https://setkab.go.id/presiden-teken-perpres-no-18-2020-tentang-rencana-pembangunanjangka-menengah-nasional-tahun-2020-2024/. [Accessed: 16-Sep-2020].

[6.] P. RI, "RENCANA PEMBANGUNAN JANGKA MENENGAH NASIONAL 20202024," Bappenas.go.id, 2020.

[7.] Bambang Dwi Anggono, "Penerapan SPBE Transformasi dari e-Government Menuju iGovernment - Ditjen Aptika," aptika.kominfo.go.id, 2019. [Online]. Available: https://aptika.kominfo.go.id/2019/02/penerapan-spbe-transformasi-dari-egovernmentmenuju-i-government/. [Accessed: 16-Sep-2020].

[8.] F. Gampfer, A. Jürgens, M. Müller, and R. Buchkremer, "Past, current and future trends in enterprise architecture-A view beyond the horizon," Comput. Ind., vol. 100, pp. 70-84, 2018.

[9.] J. Zachman, “A Framework for Information Systems Architecture," IBM, vol. 26, no. 3, 1987.

[10.] Gartner, "The Evolution of Enterprise Architecture, Before-Cloud and After-Cloud Era - Iasa Apac," https://www.gartner.com/en/documents/3894682, 2019. [Online]. Available: https://iasa-apac.org/the-evolution-of-enterprise-architecture-before-cloudand-after-cloud-era/. [Accessed: 16-Sep-2020].

[11.] Gartner, "The Evolution of Enterprise Architecture - Smarter With Gartner," IASA An Assosiation for All IT Architects, 2019. [Online]. Available: https://www.gartner.com/smarterwithgartner/the-evolution-of-enterprise-architecture/. [Accessed: 16-Sep-2020].

[12.] T. Hope, E. Chew, and R. Sharma, "The failure of success factors: Lessons from success and failure cases of enterprise architecture implementation," SIGMIS-CPR 2017 - Proc. 2017 ACM SIGMIS Conf. Comput. People Res., pp. 21-27, 2017.

[13.] Y. Gong and M. Janssen, "The value of and myths about enterprise architecture," Int. J. Inf. Manage., vol. 46, no. November 2018, pp. 1-9, 2019.

[14.] G. Shanks, M. Gloet, I. Asadi Someh, K. Frampton, and T. Tamm, "Achieving benefits with enterprise architecture,” J. Strateg. Inf. Syst., vol. 27, no. 2, pp. 139-156, 2018.

[15.] R. Oberhauser, "Rethinking Enterprise Architecture Frameworks for the Digital Age : The Digital Diamond Framework and EA Tool," vol. 12, no. 1, pp. 125-151, 2019.

[16.] A. Zimmermann, R. Schmidt, D. Jugel, and M. Möhring, "Adaptive enterprise architecture for digital transformation," in Communications in Computer and Information Science, 2016, vol. 567, pp. 308-319.

[17.] A. Zimmermann, D. Jugel, R. Schmidt, C. Schweda, and M. Möhring, "Collaborative Decision Support for Adaptive Digital Enterprise Architecture," 2015.

[18.] A. Zimmermann, R. Schmidt, K. Sandkuhl, M. Wißotzki, D. Jugel, and M. Möhring, "Digital enterprise architecture-transformation for the internet of things," in Proceedings of the 2015 IEEE 19th International Enterprise Distributed Object Computing Conference Workshops and Demonstrations, EDOCW 2015, 2015, pp. 130-138.

[19.] A. Zimmermann and J. Bogner, "Decision case management for digital enterprise architectures with the internet of things," in Smart Innovation, Systems and Technologies, 2016, vol. 57, pp. 27-37.

[20.] J. B. A. Zimmerman, "Adaptable digital enterprise architecture with microservices," 2016. 
[21.] A. Zimmermann, "Open Integration of Digital Architecture Models for Micro-granular Systems and Services - Digitale Bibliothek - Gesellschaft für Informatik e.V.," 2017. [Online]. Available: https://dl.gi.de/handle/20.500.12116/118. [Accessed: 19-Sep2020].

[22.] A. Zimmermann, R. Schmidt, K. Sandkuhl, D. Jugel, J. Bogner, and M. Mohring, "Decision management for micro-granular digital architecture," in Proceedings - IEEE International Enterprise Distributed Object Computing Workshop, EDOCW, 2017, vol. 2017-October, pp. 29-38.

[23.] R. Schmidt, M. Möhring, B. Keller, A. Zimmermann, M. Toni, and L. Di Pietro, "Digital enterprise architecture management in tourism - state of the art and future directions," in Smart Innovation, Systems and Technologies, 2018, vol. 73, pp. 93-102.

[24.] A. Zimmermann, R. Schmidt, and K. Sandkuhl, "Enterprise Composition Architecture for Micro-Granular Digital Services and Products," Int. Conf. Inf. Syst. Dev., Oct. 2018.

[25.] A. Zimmermann, R. Schmidt, K. Sandkuhl, D. Jugel, J. Bogner, and M. Möhring, "Evolution of Enterprise Architecture for Digital Transformation," in Proceedings IEEE International Enterprise Distributed Object Computing Workshop, EDOCW, 2018, vol. 2018-October, pp. 87-96.

[26.] D. Jugel, C. M. Schweda, and A. Zimmermann, "Modeling Visualization Controls for Digital Architecture and Governance," in Smart Innovation, Systems and Technologies, 2019, vol. 145, pp. 491-501.

[27.] A. Zimmermann, "On the Effect of Digitalization of Products and Services on Enterprise Architectures," AIS Electronic Library (AISeL) - International Conference on Information Systems Development (ISD), 2019. [Online]. Available: https://aisel.aisnet.org/isd2014/proceedings2019/ManagingISD/9/. [Accessed: 19-Sep2020].

[28.] A. Zimmermann, R. Schmidt, and K. Sandkuhl, "Multiple Perspectives of Digital Enterprise Architecture," 2019.

[29.] A. Zimmermann, R. Schmidt, and L. C. Jain, "Architecting the Digital Transformation: An Introduction," Springer, Cham, 2021, pp. 3-8.

[30.] A. Zimmermann, R. Schmidt, D. Jugel, and M. Möhring, "Evolution of Enterprise Architecture for Intelligent Digital Systems," in Lecture Notes in Business Information Processing, 2020, vol. 385 LNBIP, pp. 145-153.

[31.] M. Nardello, S. Han, C. Møller, and J. Gøtze, “Automated Modeling with Abstraction for Enterprise Architecture (AMA4EA): Business Process Model Automation in an Industry 4.0 Laboratory," Complex Syst. Informatics Model. Q., no. 19, pp. 42-59, 2019.

[32.] M. Nardello, S. Han, C. Møller, and J. Gøtze, "Incorporating process and data heterogeneity in enterprise architecture: Extended AMA4EA in an international manufacturing company," Comput. Ind., vol. 115, 2020.

[33.] Pemerintah RI.SPBE, "Peraturan Presiden Nomor 95 Tahun 2018 tentang Sistem Pemerintahan Berbasis Elektronik," Media Huk., p. 110, 2018.

[34.] E. I. Machdi, "Tata Kelola Sistem Pemerintahan Berbasis Elektronik," no. November, pp. 22-23, 2018.

[35.] S. Leist and G. Zellner, "Evaluation of Current Architecture Frameworks," Util. Math., vol. 78, pp. 203-237, 2009. 
[36.] L. Urbaczewski and S. Mrdalj, "a Comparison of Enterprise Architecture Frameworks," Issues Inf. Syst., vol. 7, no. 2, pp. 18-23, 2006.

[37.] N. Tiwari and V. T. Road, "Green Computing," vol. 2, no. 1, pp. 2-5, 2015.

[38.] I. S. Rozas and A. Permadi, "ISLAMIC GREEN COMPUTING,” Feb. 2018.

[39.] N. Yalina, I. S. Rozas, A. Surabaya, J. Ahmad, Y. No, and I. 117 Surabaya, "IOP Conference Series: Earth and Environmental Science Digital workplace: digital transformation for environmental sustainability Digital workplace: digital transformation for environmental sustainability."

[40.] TOGAF, "The TOGAF Standard, Version 9.2 - Architecture Principles." [Online]. Available: https://pubs.opengroup.org/architecture/togaf92doc/arch/chap20.html\#tag_20_06. [Accessed: 19-Sep-2020].

[41.] R. S. Wahono, "Romi Satria Wahono - 10 Mitos Software Engineering," Semin. Nas. Ris. dan Teknol. 2021, 2021. 